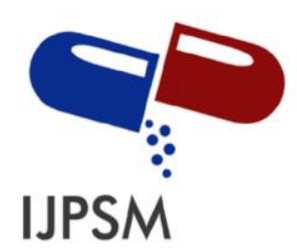

Teti Anggela Sari et al, Int. Journal of Pharmaceutical Sciences and Medicine (IJPSM),

Vol.6 Issue. 3, March- 2021, pg. 39-49

ISSN: 2519-9889

Impact Factor: 3.426

\title{
Overview of Traditional Use, Phytochemical and Pharmacological Activities of Cucumber (Cucumis sativus L.)
}

\author{
Teti Anggela Sari ${ }^{1}$; Boy Chandra ${ }^{1}$; Harrizul Rivai ${ }^{2 *}$ \\ ${ }^{1}$ College of Pharmacy (STIFARM), Jl. Raya Siteba Kurao Pagang, Padang 25147, Indonesia \\ ${ }^{2}$ Faculty of Pharmacy, Andalas University, Limau Manih Campus, Padang 25163, Indonesia \\ "Email: harrizul@yahoo.co.id and harrizul@ phar.unand.ac.id \\ DOI: 10.47760/ijpsm.2021.v06i03.004
}

\begin{abstract}
Many herbal plants are used for the treatment and prevention of various diseases. One of them is Cucumber (Cucumis sativus L.). Cucumber has high nutritional value, so that it can be used as a food source. Cucumber is used in traditional medicine for the treatment of various diseases of the human body. Therefore, it is necessary to explore information regarding the traditional uses, phytochemicals, and cucumbers' pharmacological activities. This review article aims to increase knowledge of the traditional uses, phytochemical content, and cucumbers' pharmacological activity. Data is taken from various sources such as official books, Google Scholar and ResearchGate. This data was taken in the last ten years, starting from 2011-2021. These data search results show that traditionally cucumber can be used in the treatment of various diseases. The cucumber plant's phytochemicals are reported to contain chemical constituents in the form of flavonoids, phenols, carotenoids, steroids, tannins, saponins, alkaloids, terpenoids, resins, and glycosides. Cucumbers also contain carbohydrates, protein, minerals, and vitamins. Pharmacologically, cucumbers are reported to have antioxidant, anticancer, anti-inflammatory, analgesic, antihepatotoxic, antidiabetic, antifungal, antibacterial, antidiarrheal, and thrombolytic effects. Therefore, it can be concluded that the cucumber plant (Cucumis sativus L) is a plant that is rich in chemical compounds and has the potential to be developed into phytopharmaca, especially as an antihypertensive and antidiabetic drug.
\end{abstract}

Keywords: Cucumber (Cucumis sativus L.), traditional use, phytochemical, pharmacological activity.

\section{Introduction}

Cucumbers (Cucumis sativus L.) are members of the Cucurbitaceae family, as are melons and gourds. This plant is a popular vegetable crop used in traditional Indian medicine since ancient times. These vegetables are very high in water content and very low in calories [1].

The phytochemical analysis of these plants confirms various phytochemicals such as tannins, cardiac glycosides, terpenoids, carbohydrates, resins, saponins, and phytosterols. Meanwhile, other phytochemicals such as alkaloids, flavonoids, glycosides, steroid terpenes, and phlorotannins are found in cucumber. Cucumber plants also show various pharmacological activities such as antibacterial activity, antifungal activity, cytotoxic activity, antacid and carminative activity, hepatoprotective activity, hypoglycemic and hypolipidemic activity [2].

Cucumber (Cucumis sativus L.) can be classified botanical as follows: [3]

Kingdom: Plantae

Subkingdom: Tracheobiota

Superdivision: Embryophyta

Division: Tracheophyta

Class: Magnoliopsida 


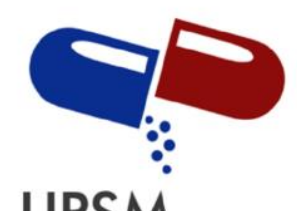

Teti Anggela Sari et al, Int. Journal of Pharmaceutical Sciences and Medicine (IJPSM), Vol.6 Issue. 3, March- 2021, pg. 39-49

ISSN: 2519-9889

Impact Factor: 3.426

Order: Cucurbitales

Family: Cucurbitaceae

Genus: Cucumis L.

Species: Cucumis sativus L.

Cucumber (Cucumis sativus L.) is an annual plant, which means that it is only for one harvest period. This plant is creeping or climbing. Cucumber leaves are green, single, broad, round leaves 7-8 cm long and 7-15 cm wide (Figure 1). Cucumber (Cucumis sativus L.) has a trumpet-like flower shape with a white or bright yellow crown (Figure 2). Cucumber fruit comes in various shapes and sizes but is generally long or round (Figure 3). Cucumber seeds are many, with a flat shape, the skin is white or yellowish-white to brown [3].

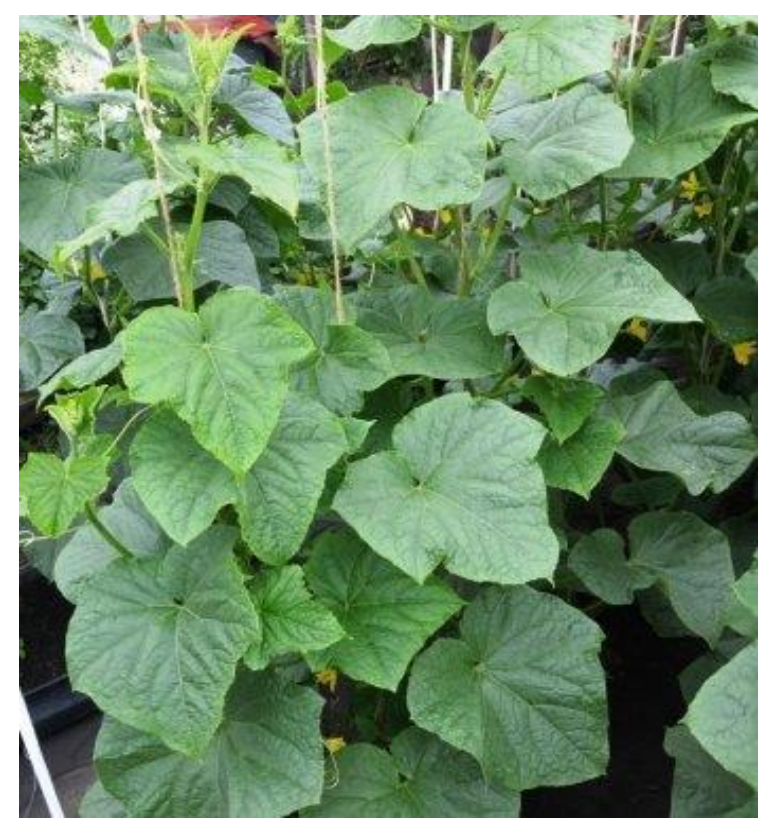

Figure 1: Leaves of Cucumber (Cucumis sativus L.) [4]

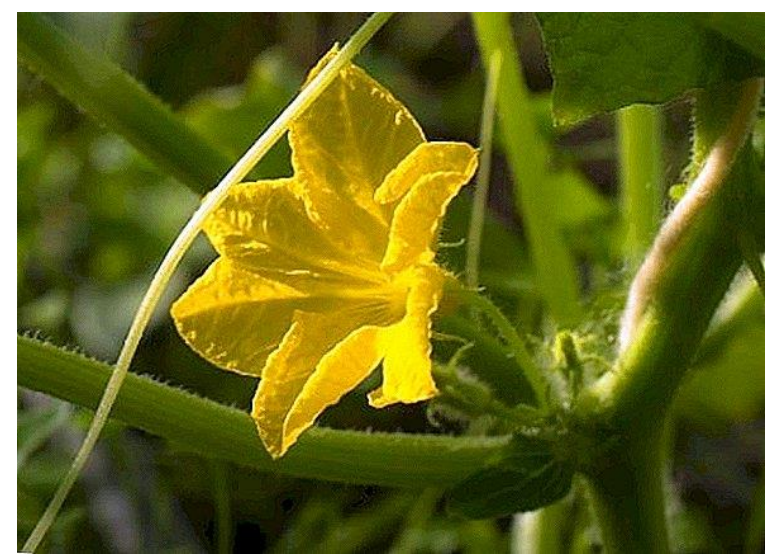

Figure 2: Flower of Cucumber (Cucumis sativus L.) [4] 


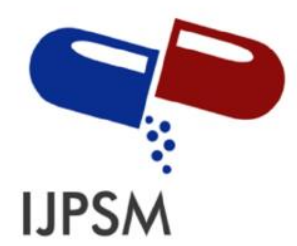

Teti Anggela Sari et al, Int. Journal of Pharmaceutical Sciences and Medicine (IJPSM), Vol.6 Issue. 3, March- 2021, pg. 39-49

ISSN: 2519-9889

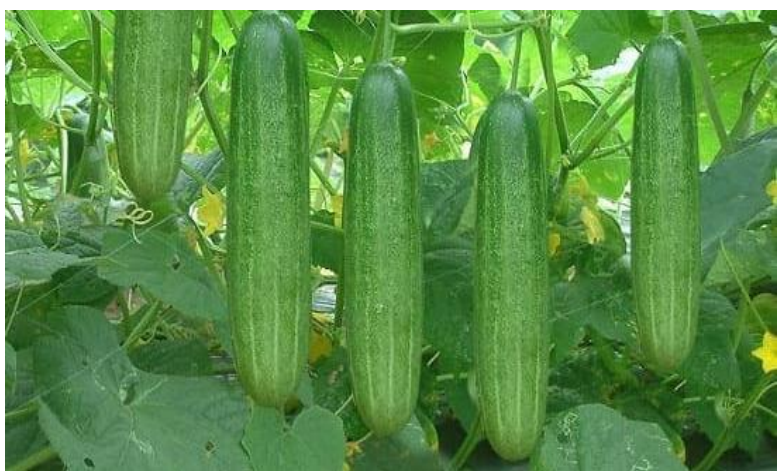

Impact Factor: 3.426

Figure 3: Cucumber Fruits (Cucumis sativus L.) [5]

\section{Methods of data collection}

This review article's preparation uses literature study techniques by looking for theoretical references relevant to the cases or problems found. Articles were collected from national and international journals in the past ten years (2011-2021). The search for data in this review article used online media through trusted sites such as Google Scholar and ResearchGate with the search keywords "Cucumis sativus L.," "cucumber," "traditional use," "phytochemicals," "pharmacological activity."

\section{Traditional use}

Cucumber (Cucumis sativus L.) has anti-acne activity in traditional use. The part taken is fresh fruit. The way of preparation is the ingredients are sliced thinly across. The way to use it is by placing it and rubbing it on the face with acne. Let it dry. After dry, rinse with warm water. Use caution on a sensitive face [6].

Cucumber (Cucumis sativus L.) can also be used as a traditional medicine to lower blood pressure. The part used is fresh fruit. The method of making is by taking two cucumbers; then, they are washed and shredded. The grated results are squeezed and filtered. How to use it is by drinking it at a dose of 2 to 3 times a day [7]. Cucumber (Cucumis sativus L.) can be used to prevent diabetes. Diabetes is a chronic disease that occurs when the pancreas does not produce enough insulin or when the body cannot effectively use the insulin produced by the pancreas. Using cucumbers is to take two fresh cucumbers (150-200 grams), wash them and then shred them. The grated results are squeezed and filtered, then drink immediately; do 2-3 times a day [8].

\section{Phytochemical review}

In phytochemical screening with color analysis, it shows that there are chemical compounds in cucumber seeds in flavonoids, tannins, saponins, and steroids. Whereas in quantitative analysis with spectrophotometry, it was found that total flavonoids were $0.36 \%(\mathrm{w} / \mathrm{w})$, total phenols $0.40 \%(\mathrm{w} / \mathrm{w})$, and titrimetric analysis obtained $2.82 \%$ tannins. Cucumber also contains $\beta$-carotene, which was analyzed by a Thin-Layer Chromatography (TLC) -scanner with a value of $2.28 \%$ [9].

Phytochemical screening of acetone extract from cucumber leaves showed chemical compounds including alkaloids, glycosides, steroids, flavonoids, saponins, and tannins [10]. Phytochemical screening of the ethanol extract of cucumber seeds showed chemical compounds in the form of flavonoids, terpenoids, tannins, cardiac glycosides, phenols, and carbohydrates [11]. Phytochemical analysis of the methanol extract of cucumber pulp showed saponins, glycosides, terpenes, phenolics, alkaloids, flavonoids, and tannins [12]. The identification of chemical compounds using the maceration method showed that cucumber's ethanol extract contains terpenoids, saponins, and phenolic chemical compounds [13].

The methanol extract of cucumber leaves (Cucumis sativus L.) contains chemicals in the form of phenols, flavonoids, carotenoids, alkaloids, tannins, and terpenes [14]. Phytochemical screening of the ethanol extract of cucumber rind (Cucumis sativus L.) contains chemical compounds in the form of alkaloids, glycosides, steroids, saponins, and tannins [15]. 


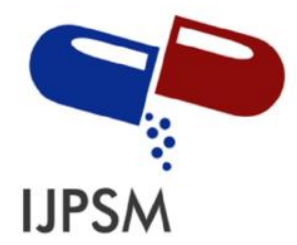

Teti Anggela Sari et al, Int. Journal of Pharmaceutical Sciences and Medicine (IJPSM), Vol.6 Issue. 3, March- 2021, pg. 39-49

ISSN: 2519-9889

Impact Factor: 3.426

The methanol extract of cucumber leaves contains primary metabolites in the form of protein $0.82 \pm 0.02 \%$, carbohydrates $2.01 \pm 0.01 \%$, saturated fat $0.03 \pm 0.02 \%$, fiber $0.99 \pm 0.01 \%$. Mineral content in the form of calcium $15.00 \pm 0.01 \mathrm{mg} / \mathrm{kg}$, phosphorus $23.00 \pm 0.01 \mathrm{mg} / \mathrm{kg}$, magnesium $13.00 \pm 0.02 \mathrm{mg} / \mathrm{kg}$, iron $0.32 \pm$ $0.01 \mathrm{mg} / \mathrm{kg}$, zinc $0.30 \pm 0.02 \mathrm{mg} / \mathrm{kg}$, and sodium $3.00 \pm 0.02 \mathrm{mg} / \mathrm{kg}$. Cucumbers also contain vitamins in the form of vitamin A $23.00 \pm 0.01 \mathrm{mg} / \mathrm{kg}$, vitamin B1 $0.03 \pm 0.01 \mathrm{mg} / \mathrm{kg}$, vitamin B2 $0.03 \pm 0.02 \mathrm{mg} / \mathrm{kg}$, vitamin B6 $0.44 \pm 0.01 \mathrm{mg} / \mathrm{kg}$, vitamin C $6.11 \pm 0.02 \mathrm{mg} / \mathrm{kg}$, vitamin E $0.09 \pm 0.01 \mathrm{mg} / \mathrm{kg}$, niacin (vitamin B3) $0.41 \pm 0.01 \mathrm{mg} / \mathrm{kg}$, and folate (vitamin B9) $15.00 \pm 0.02 \mathrm{mg} / \mathrm{kg}$ [14].

\section{Pharmacological activity}

\subsection{Antioxidant activity}

Cucumber (Cucumis sativus L.) has several pharmacological activities, including antioxidant activity from methanol extract of cucumber leaves. The number of phenolic compounds in the cucumber leaf methanol extract was $262.31 \mathrm{mg} / \mathrm{g}$ equivalent to gallic acid and $267.2 \mathrm{mg} / \mathrm{g}$ equivalent to ascorbic acid. The cucumber DPPH test showed an IC50 value of $13.06 \mu \mathrm{g} / \mathrm{mL}$, while the ascorbic acid comparison showed an IC50 value of $13.17 \mu \mathrm{g} / \mathrm{mL}[16]$.

Another study tested the antioxidant power by using cucumber juice in rabbit test animals injected subcutaneously with amoxicillin. This experiment used fifteen rabbits of the same sex, divided into three groups of 5 rabbits, each used for the study. Group A - 5 control rabbits, group B - 5 rabbits were given a subcutaneous injection of amoxicillin $30 \mathrm{mg} / \mathrm{kg}$ body weight every 24 hours for seven days followed by supplementation of $30 \mathrm{~mL}$ raw cucumber fruit juice for 14 days, and group C - 5 rabbits were given amoxicillin injection subcutaneous $30 \mathrm{mg} / \mathrm{kg}$ body weight every 24 hours and supplementation of raw cucumber juice for 14 days simultaneously. Plasma Malondialdehyde (MDA), Catalase (CAT), Superoxide dismutase (SOD), and Glutathione peroxidase (GPx) were determined in rabbits biochemically by spectrophotometry and fluorometry. The results obtained showed a significant increase in plasma Malondialdehyde (MDA) values and a significant decrease in Catalase (CAT), Superoxide dismutase (SOD), and plasma Glutathione peroxidase (GPx) when rabbits were given $30 \mathrm{mg} / \mathrm{kg}$ BW subcutaneous injection of amoxicillin. However, this significant biochemical change was reversed in rabbits when supplemented with 30 $\mathrm{mL}$ raw cucumber fruit juice [17].

Cucumber (Cucumis sativus L.) has antioxidant effects. This test was carried out in vitro using cucumber water extract at 250 and $500 \mu \mathrm{g} / \mathrm{ml}$. Free radical scavenging compared to ascorbic acid, BHA (Butylated hydroxyl anisole). Cucumber fruit extracts showed maximum antioxidant effect at $500 \mu \mathrm{g} / \mathrm{ml}$ each. The presence of flavonoids and tannins in the extract, as evidenced by phytochemical screening, suggests that these compounds are responsible for the free radical scavenging effect [18].

\subsection{Anticancer activity}

Cancer is a disease in which body tissue cells' growth is abnormal, fast, and uncontrolled [19]. Cucumber (Cucumis sativus L.) has many pharmacological activities, including anticancer activity. The anticancer potential of the cucumber plant (Cucumis sativus L.) was determined by in vitro culture. Methanol and acetone extracts were used to analyze cytotoxicity against Michigan Cancer Foundation-7 cancer cell line (MCF) and cervical cancer cell line (HeLa) by testing using a multi-tie tamper (MTT). The results showed that the methanol extract of cucumber had cytotoxicity activity against the Michigan Cancer Foundation-7 (MCF) and cervical cancer (HeLa) cancer cell lines with IC50 values of $15.6 \pm 1.3 \mu \mathrm{g} / \mathrm{mL}$ and $28.2 \pm 1 \mu \mathrm{g} / \mathrm{mL}$. Acetone extract has an IC50 value above $50 \mu \mathrm{g} / \mathrm{mL}$, so it is unable to inhibit Michigan Cancer Foundation-7 (MCF) and cervical cancer (HeLa) cells [10].

This study explains that cucumber has pharmacological activity as an anticancer in liver cancer. The part used is the cucumber flower. The isolated compound from the ethyl acetate fraction of cucumber flower was tested for its anticancer activity against HePG2 liver cancer cells at concentrations of $1000 \mu \mathrm{g} / \mathrm{mL}, 500 \mu \mathrm{g} / \mathrm{mL}, 250$ $\mu \mathrm{g} / \mathrm{mL}, 125 \mu \mathrm{g} / \mathrm{mL}$, and $62.5 \mu \mathrm{g} / \mathrm{mL}$ showed the results of\% CTC50 Cytotoxicity $82.15 \mu \mathrm{g} / \mathrm{mL}, 73.06 \mu \mathrm{g} /$ $\mathrm{mL}, 69.74 \mu \mathrm{g} / \mathrm{mL}, 56.21 \mu \mathrm{g} / \mathrm{mL}$ and $49.83 \mu \mathrm{g} / \mathrm{mL}$ against the HePG2 cell line of human liver cancer by MTT assay (Figure 4). While the value of CTC50 against liver cancer cells HePG2 cells. was $103.7 \mu \mathrm{g} / \mathrm{mL}$ [20]. 


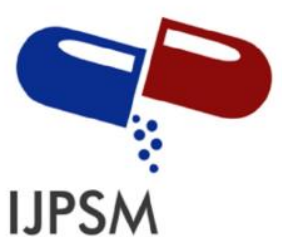

Teti Anggela Sari et al, Int. Journal of Pharmaceutical Sciences and Medicine (IJPSM), Vol.6 Issue. 3, March- 2021, pg. 39-49

ISSN: 2519-9889

Impact Factor: 3.426

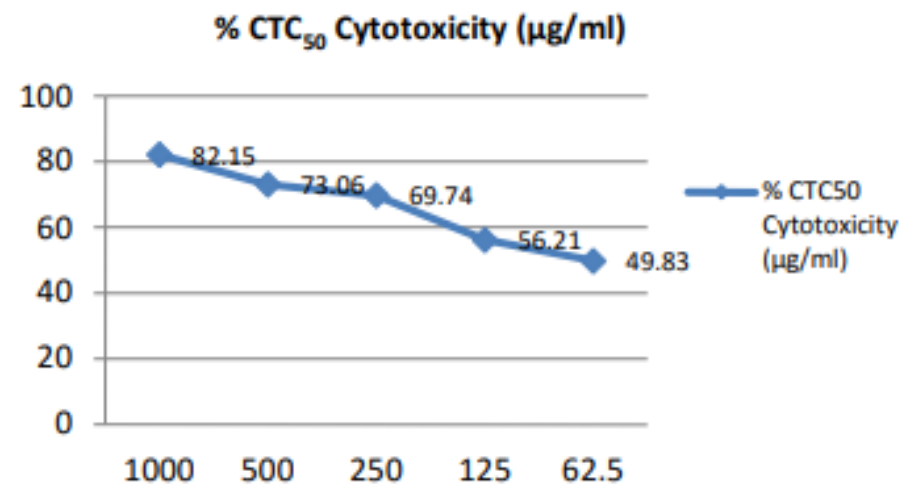

Figure 4: Graphic presentation of CTC50 isolated from ethyl acetate fraction of cucumber flower against human liver cancer cells HePG2 cells

Qualitative analysis reports that the ethanol extract of cucumber leaves contains chemical compounds in the form of glycosides, alkaloids, tannins, proteins, amino acids, phytosterols, steroids, terpenoids, and saponins. The anticancer activity of the ethanol extract of cucumber leaves on HeLa and HepaG2 cancer cells was tested using the MTT Assay method. The ethanol extract of cucumber leaves at doses of $62.5 \mu \mathrm{g}, 125 \mu \mathrm{g}, 250 \mu \mathrm{g}$, $500 \mu \mathrm{g}$ produced significant anticancer activity against HeLa and HepG2 cancer cells. Compared with the \% inhibition of HeLa and HepG2 cells, HepG2 cells provide more significant activity than HeLa cells. (Figure 5). The results of this study indicate that the triterpenoids present in the ethanol extract of cucumber leaves have anticancer activity [21],

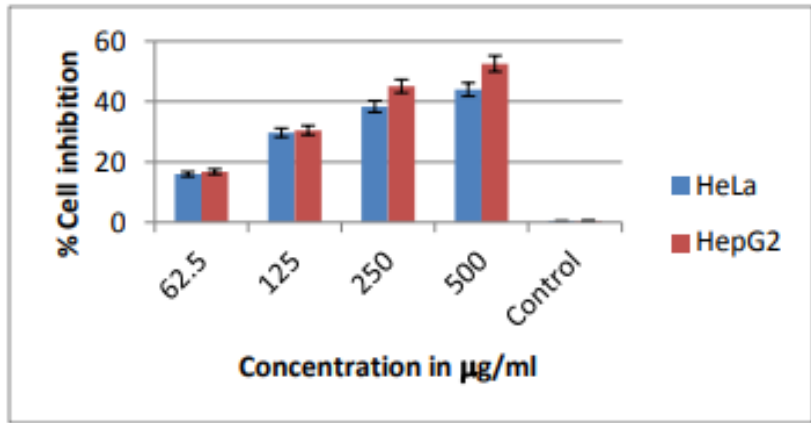

Figure 5: A comparison chart of cucumber leaves ethanol extract in inhibiting Hela and HepG2 cells [21]

\subsection{Anti-inflammatory activity}

Cucumber (Cucumis sativus L.) has anti-inflammatory activity. Cucumber leaf methanol extract (MCS) was studied using mice at two different doses, namely 150 and $250 \mathrm{mg} / \mathrm{kg}$ body weight. The effect was compared with standard indomethacin $(10 \mathrm{mg} / \mathrm{kg}$ body weight). This study showed the highest anti-inflammatory activity at a dose of $250 \mathrm{mg} / \mathrm{kg}$. In the formalin test, extracts at both doses (150 and $250 \mathrm{mg} / \mathrm{kg}$ body weight) significantly prevented the increase in leg edema volume. Cucumber leaf methanol extract (MCS) significantly reduced inflammation by $57.35 \%$ (150 mg / $\mathrm{kg}$ body weight) and $72.06 \%$ (250 mg / kg body weight) compared to the standard drug indomethacin $(79.41 \%)$ [16].

\subsection{Analgetic activity}

Cucumber (Cucumis sativus L.) has pharmacological activity as an analgesic. Analgesic testing on cucumber methanol extract was carried out on mice with the writhing method, given a $250 \mathrm{mg} / \mathrm{kg}$ and $500 \mathrm{mg} / \mathrm{kg}$ body 


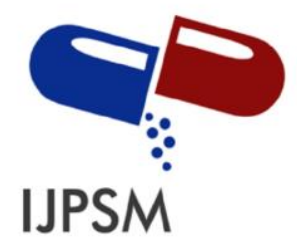
Teti Anggela Sari et al, Int. Journal of Pharmaceutical Sciences and Medicine (IJPSM),
Vol.6 Issue. 3, March- 2021, pg. 39-49

ISSN: 2519-9889

Impact Factor: 3.426

weight. This study showed that cucumber methanol extract was able to inhibit pain by $54.72 \%$ and $55.66 \%$, compared to the administration of Na-diclofenac (76.41\%) [22].

Another study tested cucumber's juicy fruit extract against analgesic activity and free radical scavenging. The extract was subjected to in vitro assay for analgesic activity at a dose of $500 \mathrm{mg} / \mathrm{kg}$. This analgesic effect is compared with sodium-diclofenac $(50 \mathrm{mg} / \mathrm{kg})$. Cucumber fruit extract shows a maximum analgesic effect of $500 \mathrm{mg} / \mathrm{kg}$. The presence of flavonoids and tannins in the extract, as evidenced by the initial phytochemical screening, indicated that these compounds were responsible for the analgesic effect [18].

\subsection{Antihepatotoxic activity}

The liver is an organ that has an important function for metabolism in the body. Hepatotoxic compounds can cause damage to the liver. Cucumber (Cucumis sativus L.) has pharmacological activity as an antihepatotoxic. Hepatotoxic testing on cucumbers can be seen in tests using rat test animals. Rats were injected intraperitoneally as much as $1 \mathrm{~mL} \mathrm{CCl} / \mathrm{kg}$ body weight in olive oil (1: 1). Then the rats were given ethanol extract from cucumber at doses of 350 and $700 \mathrm{mg} / \mathrm{kg}$ body weight. The results showed that the cucumber methanol extract had antihepatotoxic activity, which could be seen from the activity to increase ALP, SGPT, SGOT, and TBIL and reduce the effect of carbon tetrachloride (CCl4). Hepatotoxic activity at a dose of 350 $\mathrm{mg} / \mathrm{kg}$ obtained ALP values of 265.2 \pm 7,314 IU / L, SGPT 149.1 $\pm 5,575 \mathrm{IU} / \mathrm{L}, \mathrm{SGOT} 252.2 \pm 9,178 \mathrm{IU} / \mathrm{L}$, and TBIL $1.473 \pm 0.047$. whereas at a dose of $700 \mathrm{mg} / \mathrm{kg}$ the ALP value was $217.8 \pm 8.669 \mathrm{IU} / \mathrm{L}$, SGPT $128.1 \pm 9,083$, SGOT $198.4 \pm 4.583$, and TBIL $1.052 \pm 0.047$. The best value of cucumber methanol extract's hepatotoxic activity was $700 \mathrm{mg} / \mathrm{kg}$ [23].

Another study used cucumber juice (Cucumis sativus $\mathrm{L}$.) with test animal mice injected intra-peritoneally at 2.5 $\mathrm{mL} \mathrm{CCl4} \mathrm{/} \mathrm{kg}$ (ratio 1: 1, v / v in olive oil). They are giving cucumber juice (Cucumis sativus L.) in 3 variations of doses, namely $10 \mathrm{mg} / \mathrm{kg}, 100 \mathrm{mg} / \mathrm{kg}$, and $500 \mathrm{mg} / \mathrm{kg}$ of cucumber juice (Cucumis sativus $\mathrm{L}$.). The results show that the best concentration is $10 \mathrm{mg} / \mathrm{kg}$, which shows a protective effect on the body with the activity value of the enzyme aspartate aminotransferase (AST) of $53 \mathrm{IU} / \mathrm{L}$, alanine aminotransferase (ALT) $125 \mathrm{IU} / \mathrm{L}$, and blood urea nitrogen (BUN) $18.8 \mathrm{mg}$. / dL [24].

\subsection{Antidiabetic activity}

Diabetes mellitus is a type of disease caused by a decrease in the pancreatic lender's hormone insulin. This hormone decrease results in all the sugar (glucose) consumed by the body cannot be processed completely [25]. Cucumber (Cucumis sativus L.) has pharmacological activity as an antidiabetic. The hypoglycemic effect of the methanol fruit pulp extract of cucumber (Cucumis sativus L.) was tested in alloxan-induced diabetic rats. The methanol extract of cucumber pulp was given as much as $500 \mathrm{mg} / \mathrm{kg}$ body weight orally to alloxaninduced diabetic rats. This extract significantly decreased the blood glucose concentration from $231.25 \pm 1.11$ $(\mathrm{mg} / \mathrm{dL})$ to $82.25 \pm 1.55(\mathrm{mg} / \mathrm{dL})$. The standard antidiabetic drug (glibenclamide) given orally at $5 \mathrm{mg} / \mathrm{kg}$ body weight also significantly decreased the blood glucose concentration from $189.00 \pm 2.42(\mathrm{mg} / \mathrm{dL})$ to $61.00 \pm 2.48(\mathrm{mg} / \mathrm{dL})$. Therefore, this study revealed that the methanol extract of cucumber pulp contains active substances with hypoglycemic activity and can be used to treat diabetes mellitus [12].

Other studies have shown that hydroalcoholic and butanol extracts from cucumber seeds have pharmacological activity as antidiabetic. This extract was tested on normal male rats and diabetes induced by Streptozotocin 60 $\mathrm{mg} / \mathrm{kg}$ intraperitoneally. The dosages of cucumber seed hydroalcoholic extract $(0.2,0.4,0.8 \mathrm{~g} / \mathrm{kg})$, cucumber seed butanol extract $(0.2,0.4,0.8 \mathrm{~g} / \mathrm{kg})$ and glibenclamide $(1$ and $3 \mathrm{mg} / \mathrm{kg}) \mathrm{kg}$ ) and treatment was continued for 9 days. Blood samples were taken at $0,1,2,3,4,8$ hours on the first day and day 9 (216 hours) to measure blood glucose levels. The results showed that the hydroalcoholic extract of cucumber seeds (22.5-33.8\%) and butanol extract of cucumber seeds (26.6-45.0\%) effectively reduced blood glucose levels and controlled weight loss in diabetic rats after nine days of treatment. Glibenclamide can reduce blood glucose levels in normal rats (27.8-31.0\%) and diabetic rats (36.0-50.0\%) after nine treatment days. It suggests that the hydroalcoholic and butanol extracts of cucumber seeds effectively reduce blood glucose levels in diabetic rats [26]. 


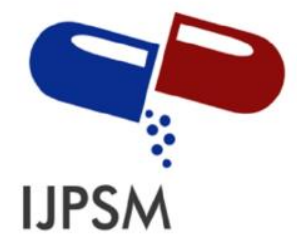

Teti Anggela Sari et al, Int. Journal of Pharmaceutical Sciences and Medicine (IJPSM), Vol.6 Issue. 3, March- 2021, pg. 39-49

ISSN: 2519-9889

Impact Factor: 3.426

\subsection{Antifungal activity}

Cucumber (Cucumis sativus L.) has antifungal activity. Antifungal is a compound that can kill or inhibit fungal growth. The antifungal activity can be seen from testing the ethanol extract of cucumber $80 \mu \mathrm{g} /$ disc compared to standard $30 \mu \mathrm{g} /$ disc griseofulvin using Aspergillus niger, Blastomyces dermatitis, Candida albicans, Pityrosporum ovale, Trichophyton spp., Microsporum spp. The results of testing the cucumber ethanol extract activity of $80 \mu \mathrm{g} /$ disc with the standard drug griseofulvin $30 \mu \mathrm{g} /$ disc can be seen in the fungus Blastomyces dermatittidis. The inhibition of the ethanol extract of cucumber (Cucumis sativus L.) in the fungus Blastomyces dermatitis was $2.15 \mathrm{~mm}$, whereas the standard drug griseofulvin was $3.25 \mathrm{~mm}$ (Table 1). The results of this study indicated that the ethanol extract of cucumber had antifungal effects [15].

Table 1: Antifungal activity of the ethanol extract of cucumber (Cucumis sativus L.) and the standard drug griseofulvin [15]

\begin{tabular}{lcc}
\hline Tested Fungi & $\begin{array}{c}\text { Zone of inhibition (mm) by the crude ethanol } \\
\text { extract of Cucumis sativus (80 } \mathrm{gg} / \text { disc) }\end{array}$ & $\begin{array}{c}\text { Standard drug, Griseofulvin } \\
\text { (30 } \mathrm{gg} / \mathrm{disc})\end{array}$ \\
\hline Aspergillus niger & 3.45 & 5.5 \\
Blastomyces dermatitides & 2.15 & 3.25 \\
Candida albicans & 1.75 & 3.95 \\
Pityrosporum ovale & 2.25 & 4.5 \\
Trichophyton spp & 2 & 3.9 \\
Microsporum spp & 1.5 & 4
\end{tabular}

Testing of cucumber seed extract to evaluate the antimicrobial activity against Alternaria, Acremonium, Verticillium, Pythium, and Trichoderma fungi by diffusion method has been carried out in other studies. The results of this study stated that the cucumber seed ethanol extract was the most active in inhibiting Pythium fungi $(17.0 \mathrm{~mm})$ and less inhibiting Alternaria fungi $(8.0 \mathrm{~mm})$. The $\mathrm{N}$-hexane fraction was very active in inhibiting Pythium (20.0 mm) fungi, DCM (Dichloromethane) was more active in inhibiting Acremonium (20 $\mathrm{mm}$ ), and ethyl acetate more actively inhibiting Acremonium (16.0 mm) fungi (Table 2) [11].

Table 2: Antifungal activity of cucumber seed extract. Zone of inhibition in mm, concentration in $\mu \mathrm{g} / \mathrm{mL}[11]$

\begin{tabular}{|c|c|c|c|c|c|}
\hline Sample & Alternaria & Acremonium & Verticellium & Pythium & Trichoderma \\
\hline $\begin{array}{c}\text { Crude ethanolic } \\
\text { extract }\end{array}$ & $8.0 \pm 0.12$ & $15.0 \pm 0.19$ & $1.04 \pm 0.15$ & $17.0 \pm 0.21$ & $15.0 \pm 0.21$ \\
\hline n-hexane & $6.0 \pm 0.19$ & $14.0 \pm 0.12$ & $11.0 \pm 0.09$ & $20.0 \pm 0.09$ & $14.0 \pm 0.13$ \\
\hline DCM & $7.0 \pm 0.19$ & 20.00 .09 & $14.5 \pm 0.08$ & $10.5 \pm 0.16$ & $14.5 \pm 0.09$ \\
\hline Ethyl acetate & $7.0 \pm 0.11$ & $16.0 \pm 0.09$ & $13.0 \pm 0.12$ & $8.5 \pm 0.02$ & $8.5 \pm 0.12$ \\
\hline
\end{tabular}

Antifungal activity was also shown in ethanol extract and chloroform extract of cucumber leaves and stems at a dose of $80 \mu \mathrm{g} /$ disc compared to the standard drug griseofulvin at a dose of $30 \mu \mathrm{g} / \mathrm{disc}$, against Aspergillus niger, Blastomyces dermatitis, Candida albicans, Pityrosporum ovale. Trichophyton spp, and Microsporum spp. The ethanol extract and chloroform extract of cucumber showed moderate antifungal activity against all the test organisms used in this study. The inhibition zone of the ethanol extract of cucumber leaves and stems was $4.40 \pm 0.18$ to $1.67 \pm 0.08 \mathrm{~mm}$, and the inhibition zone of the chloroform extract of cucumber leaves and stems was $3.45 \pm 0.04$ to $1.50 \pm 0.12 \mathrm{~mm}$. Simultaneously, the inhibition zone of the standard drug griseofulvin was $10.97 \pm 0.16$ to $11.42 \pm 0.30$. Thus, Aspergillus niger is the fungus most susceptible to ethanol extract and chloroform of cucumber leaves and stems (Table 3). It can be concluded that the ethanol extract and chloroform of cucumber leaves and stems have antifungal activity [27]. 


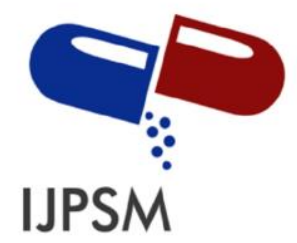

Teti Anggela Sari et al, Int. Journal of Pharmaceutical Sciences and Medicine (IJPSM), Vol.6 Issue. 3, March- 2021, pg. 39-49

ISSN: 2519-9889

Impact Factor: 3.426

Table 3: Antifungal activity of ethanol extract and chloroform extract of cucumber leaves and stems. Zone of inhibition in $\mathrm{mm}$ and concentration in $\mu \mathrm{g} / \mathrm{mL}$ [27]

\begin{tabular}{|c|c|c|c|}
\hline \multirow[b]{2}{*}{ Tested fungal strains } & \multicolumn{3}{|c|}{ Zone of inhibition in millimeter (mm) } \\
\hline & $\begin{array}{l}\text { Ethanolic } \\
\text { extract of Cucumis } \\
\text { satiuss ( } 80 \mu \mathrm{g} \mathrm{dis}^{-1} \text { ) }\end{array}$ & $\begin{array}{l}\text { Chloroform } \\
\text { extract of Cucumis } \\
\text { sativus ( } 80 \mu \mathrm{g} \mathrm{dise} \mathrm{c}^{-1} \text { ) }\end{array}$ & $\begin{array}{l}\text { Positive control } \\
\text { [standard drug, } \\
\text { griseofulvin }\left(30 \mu \mathrm{g} \mathrm{disc}^{-1}\right) \text { ] }\end{array}$ \\
\hline Aspergillus niger & $4.40 \pm 0.18$ & $3.45 \pm 0.04$ & $10.97 \pm 0.16$ \\
\hline Blastomyces dermatitides & $3.20 \pm 0.15$ & $2.15 \pm 0.12$ & $12.07 \pm 0.06$ \\
\hline Candida albicans & $2.08 \pm 0.05$ & $1.75 \pm 0.20$ & $12.27 \pm 0.36$ \\
\hline Pityrosporum ovale & $2.45 \pm 0.22$ & $2.25+0.08$ & $14.00 \pm 0.12$ \\
\hline Trichophyton spp. & $2.13 \pm 0.02$ & $2.00 \pm 0.04$ & $12.97 \pm 0.65$ \\
\hline Microsporum spp. & $1.67 \pm 0.08$ & $1.50=0.12$ & $11,42 \pm 0,30$ \\
\hline
\end{tabular}

\subsection{Antibacterial activity}

One of the cucumber plant's pharmacological activities is antibacterial. Antibacterial is a compound that can control bacterial growth. This study was used to evaluate the antimicrobial activity against bacteria by the diffusion method. The results of this study indicated that the ethanol extract of cucumber seeds was the most active in inhibiting Staphylococcus aureus $(21.5 \mathrm{~mm})$ and less of Shigella flexneri $(17.0 \mathrm{~mm})$. The $\mathrm{n}$-hexane fraction was very active in inhibiting Salmonella typhi bacteria $(26 \mathrm{~mm})$. Dichloromethane fraction more actively inhibited Escherichia coli $(16.25 \mathrm{~mm})$, and ethyl acetate fraction more actively inhibited Salmonella typhi bacteria (16.0 $\mathrm{mm})$ (Table 4) [11].

Table 4: Antibacterial activity of extracts from cucumber seeds. Zone of inhibition in mm, concentration in $\mu \mathrm{g}$ $/ \mathrm{mL}[11]$

\begin{tabular}{|c|c|c|c|c|c|}
\hline Sample & $\begin{array}{c}\text { Staphylococcus } \\
\text { aurous }\end{array}$ & $\begin{array}{c}\text { Shigella } \\
\text { flexneri }\end{array}$ & $\begin{array}{c}\text { Pseudomonas } \\
\text { aeruginosa }\end{array}$ & $\begin{array}{c}\text { Escherichia } \\
\text { coli }\end{array}$ & $\begin{array}{c}\text { Salmonella } \\
\text { typhi }\end{array}$ \\
\hline $\begin{array}{c}\text { Crude ethanolic } \\
\text { extract }\end{array}$ & $21.5 \pm 0.02$ & $17.0 \pm 0.22$ & $20.9 \pm 0.03$ & $22.5 \pm 0.06$ & $20.0 \pm 0.31$ \\
\hline n-hexane & $19.0 \pm 0.21$ & $10.0 \pm 0.03$ & $09.2 \pm 0.21$ & $18.25 \pm 0.11$ & $26.0 \pm 0.19$ \\
\hline DCM & $10.15 \pm 0.12$ & $12.0 \pm 0.19$ & $07.15 \pm 0.14$ & $16.25 \pm 0.15$ & $14.5 \pm 0.14$ \\
\hline Ethyl acetate & $11.5 \pm 0.11$ & $13 \pm 0.09$ & $07.5 \pm 0.12$ & $14.5 \pm 0.13$ & $16.0 \pm 0.15$ \\
\hline
\end{tabular}

\subsection{Antidiarrheal activity}

Cucumber has antidiarrheal activity. The antidiarrheal effect test was carried out on mice using methanol extract of cucumber leaves. The extract was given to mice as much as $500 \mathrm{mg} / \mathrm{kg}$ of body weight orally. The mice were induced with castor oil first. This study indicated that the methanol extract of cucumber leaves had a fecal inhibitory activity of $62.5 \%$. The comparison of loperamide with a dose of $3 \mathrm{mg} / \mathrm{kg}$ body weight showed an inhibitory value of $100 \%$. It suggests that cucumber has the potential to be antidiarrheal [22].

\subsection{Thrombolytic activity}

Cucumber fruit methanol extract has been reported to have thrombolytic effects. The test was carried out using in vitro. Blood samples from volunteers were taken as much as $5 \mathrm{~mL}$. Prepare ten microcentrifuge tubes, put the blood sample into the microcentrifuge tube with each tube containing $0.5 \mathrm{~mL}$ of the blood sample. After that, the blood samples were incubated for 45 minutes at $37^{\circ} \mathrm{C}$, then tested by inserting the cucumber methanol extract into the blood clots in tubes $1,2,3,6,7,8,9$, and 10 , each $100 \mu \mathrm{L}$. Tube number 5 was inserted 100 $\mu \mathrm{L}$ streptokinase (standard drug) as a positive control, and in tube number 4 was added water as a negative 


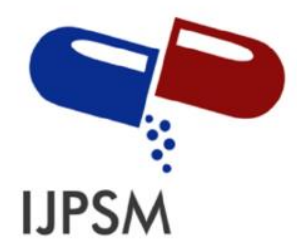

Teti Anggela Sari et al, Int. Journal of Pharmaceutical Sciences and Medicine (IJPSM), Vol.6 Issue. 3, March- 2021, pg. 39-49

ISSN: 2519-9889

Impact Factor: 3.426

control. The results showed that cucumber had a moderate thrombolytic activity with an average value of $45.15 \%$ compared to the thrombolytic effect of streptokinase of $81.7 \%$ and water of $7.35 \%$ (Figure 6). It suggests that cucumber has moderate thrombolytic activity [28].

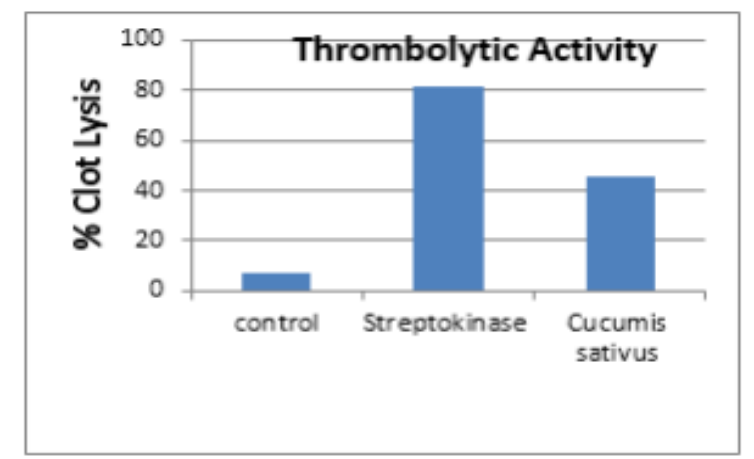

Figure 6: \% Clot lysis streptokinase and methanol extract from cucumber [28]

Another study showed that the thrombolytic effect of methanol extract of cucumber leaves was $29.33 \%$, while the streptokinase comparison showed a blood clot breakdown value of $65.26 \%$. It shows that the methanol extract of cucumber leaves is less effective as a thrombolytic [22].

\section{Conclusion}

The cucumber plant (Cucumis sativus L.) is a plant that has been used traditionally to treat various diseases. This plant is rich in chemical compounds that are scattered in every part of the plant. This plant has various pharmacological activities such as antioxidant, anticancer, anti-inflammatory, analgesic, antihepatotoxic, antidiabetic, antifungal, antibacterial, antidiarrheal, and thrombolytic. Therefore, the cucumber plant can be developed into phytopharmaca as a medicine for various diseases, significantly as a phytopharmaca to help relieve hypertension and diabetes.

\section{References}

[1]. Mukherjee PK, Nema NK, Maity N, Sarkar BK. Phytochemical and therapeutic potential of cucumber. Fitoterapia. 2013 Jan 1;84:227-236.

[2]. Sahu T, Sahu J. Cucumis sativus (cucumber): a review on its pharmacological activity. Journal of Applied Pharmaceutical Research. 2015 Jan 25;3(1):04-9.

[3]. https://www.teorieno.com/2016/10/klasifikasi-dan-morfologi-mentimun.html

[4]. http://gg.gg/gambar-daun-bunga-mentimun

[5]. http://gg.gg/gambar-buah-mentimun

[6]. Mentri Kesehatan Republik Indonesia. Formularium Ramuan Obat Tradisional Indonesia. Menteri Kesehatan Republik Indonesia. Nomor HK.0107/MENKES/187/2017.

[7]. Badan Pengawas Obat dan Makanan RI. Acuan sediaan herbal. Jakarta: Badan Pengawas Obat dan Makanan RI.Volume 2.(Edisi pertama). 2006

[8]. Putri T. Tangkis diabetes dan racun dalam tubuh dengan mentimun. Yogyakarta. Laksana. 2019.

[9]. Mandey JS, Wolayan FR, Pontoh CJ, Sondakh BF. Phytochemical characterization of cucumber (Cucumis sativus L.) seeds as candidate of water additive for organic broiler chickens. Journal of Advanced Agricultural Technologies. 2019 Mar;6(1).

[10]. Tuama AA, Mohammed AA. Phytochemical screening and in vitro antibacterial and anticancer activities of the aqueous extract of Cucumis sativus. Saudi journal of biological sciences. 2019 Mar 1;26(3):600-604.

[11]. Begum HA, Asad F, Sadiq A, Mulk S, Ali K. 44. Antioxidant, antimicrobial activity and phytochemical analysis of the seeds extract of Cucumis sativus Linn. Pure and Applied Biology (PAB). 2019 Mar 1;8(1):433-441. 


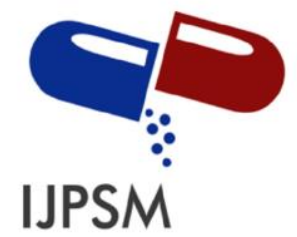

\section{Teti Anggela Sari et al, Int. Journal of Pharmaceutical Sciences and Medicine (IJPSM), Vol.6 Issue. 3, March- 2021, pg. 39-49}

[12]. Saidu AN, Oibiokpa FI, Olukotun IO. Phytochemical screening and hypoglycemic effect of methanolic fruit pulp extract of Cucumis sativus in alloxan-induced diabetic rats. Journal of Medicinal Plants Research. 2014 Oct 17;8(39):1173-1178.

[13]. Hakim AR, Saputri R. Identifikasi senyawa kimia ekstrak etanol mentimun (Cucumis sativus L.) dan ekstrak etanol nanas (Ananas comosus (L) Merr). Jurnal Pharmascience, 2017 Feb;04(01):34-8.

[14]. Essien AD. Comparative studies of the phytochemistry, proximate analysis, mineral and vitamin compositions of the methanol leaf extracts of Cucumis sativus L. and Daucus carota L. IJPR. 2016;6(08):282-285

[15]. Mallik J, Akhter R. Phytochemical screening and in-vitro evaluation of reducing power, cytotoxicity and antifungal activities of ethanol extracts of Cucumis sativus. International Journal of Pharmaceutical \& Biological Archives. 2012;3(3):555-560.

[16]. Nasrin F, Bulbul IJ, Aktar F, Rashid MA. Anti-inflammatory and antioxidant activities of Cucumis sativus leaves. Bangladesh Pharmaceutical Journal. 2015 Jul 26;18(2):169-173.

[17]. Olaniyan MF, Afolabi T. Scavenging antioxidative bioactivities of cucumber (Cucumis sativus) fruit juice in rabbits overdosed with amoxicillin. Biomedical and Biotechnology Research Journal (BBRJ). 2018 Oct 1;2(4):276-280.

[18]. Kumar D, Kumar S, Singh J, Vashistha BD, Singh N. Free radical scavenging and analgesic activities of Cucumis sativus L. fruit extract. Journal of Young Pharmacists. 2010 Oct 1;2(4):365-368.

[19]. Dalimartha S. Ramuan tradisional untuk pengobatan kanker. PT Penebar Swadaya. Jakarta. 2003.

[20]. Muruganantham N, Solomon S, Senthamilselvi MM. Anticancer activity of Cucumissativus (Cucumber) flowers against Human Liver Cancer. International Journal of Pharmaceutical and Clinical Research. 2016;8(1):39-41.

[21]. Swaminathan G, Sundaram RS, Mamatha M, Vaijayanthimala P. Evaluation of in vitro anticancer activity of Cucumis sativus Linn leaves. International Journal of Research in Pharmacology \& Pharmacotherapeutics. 2015;4(2):223-9.

[22]. Akter A, Begh MZ, Islam F, Afroz T, Hossain MS, Faysal M, Rahman MM. Phytochemical Screening and Evaluation of Thrombolytic, Analgesic and Antidiarrhoeal Activity of the Leaves of Cucumis sativus Linn. (Cucurbitaceae) of Methanolic Extracts. Journal of Pharmaceutical Sciences and Research. 2020 Mar 1;12(3):448451.

[23]. Dhande SR, Dongare PP, Shah PR, Joshi YM, Kadam VJ. Antihepatotoxic potential of Cucumis sativus and Pogostemon patchouli against carbon tetrachloride induced hepatotoxicity. Indo American Journal of Pharmaceutical Research. 2013;3(11):9212-9221.

[24]. Bajpai VK, Kim JE, Park YH, Kang SC. In vivo Pharmacological Effectiveness of Heat-treated Cucumber (Cucumis sativus L.) Juice against CCI4 - induced Detoxification in a Rat Model. Indian Journal of Pharmaceutical Education and Research, Vol-51(2) 2017:280-287.

[25]. Prapti Utami dan Tim Lentera. Tanaman Obat Untuk Mengatasi Diabetes Mellitus. Jakarta. AgroMedia Pustaka. 2003.

[26]. Minaiyan M, Zolfaghari B, Kamal A. Effect of hydroalcoholic and buthanolic extract of Cucumis sativus seeds on blood glucose level of normal and streptozotocin-induced diabetic rats. Iranian journal of basic medical sciences. 2011 Sep;14(5):436-442.

[27]. Das J, Chowdhury A, Biswas SK, Karmakar UK, Syarif SR, Raihan SZ, Muhit MA. Cytotoxicity and antifungal activities of ethanolic and chloroform extracts of Cucumis sativus Linn (Cucurbitaceae) leaves and stems. Research Journal of Phytochemistry. 2012;6(1):25-30.

[28]. Siddika M, Hasnat R, Bahar E. Thrombolytic (in vitro) and analgesic (in vivo) effect of methanolic extract of Cucumis sativus. The Pharma Innovation Journal 2015; 3(12): 01-07. 


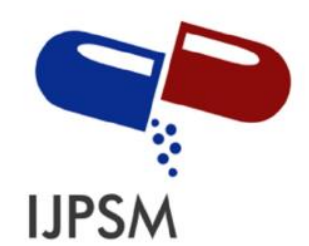

Teti Anggela Sari et al, Int. Journal of Pharmaceutical Sciences and Medicine (IJPSM), Vol.6 Issue. 3, March- 2021, pg. 39-49

ISSN: 2519-9889

Impact Factor: 3.426

\section{A Brief Author Biography}

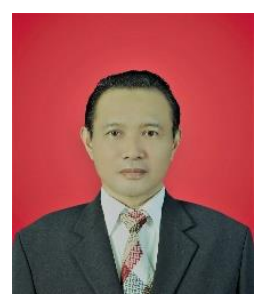

Prof. Dr. Harrizul Rivai, M.S., was born in Payakumbuh, West Sumatra, on 4 September 1953. His father is Rivai Said, and his mother is Saridahanum Syofyan. The Author obtained a Bachelor of Pharmacy from the Department of Pharmacy, Faculty of Mathematics and Natural Sciences, Padjajaran University, Bandung (1976), a Master of Science degree from the Bandung Institute of Technology (1984), and a Doctorate from the Department of Chemistry, Faculty of Mathematics and Natural Sciences, Andalas University, Padang (2011). Now the Author is a Professor and Researcher at the Faculty of Pharmacy, Andalas University, Padang. The Author also serves as Deputy Chair of Academic Affairs at the YPTIK Padang College of Pharmacy (STIFARM). The Author wrote the book "Principles of Chemical Examination" (Publisher UI-Press, 1995), translated the book "Pharmaceutical Statistics" (EGC Medical Book Publishers, 2010), and wrote "Chapter 4" in the book "Recent Research Advances in Biology Vol. 4 "(International Book Publisher, India, and United Kingdom, 2020). The Author has also written articles in various international journals in various science fields, such as chemistry, biology, and pharmacy. 